\title{
Ménière병의 내과적 치료
}

성균관대학교 의과대학 삼성서울병원 이비인후과학교실

정 원 호.이 현 석

\section{Medical Treatment of Ménière's Disease}

Won-Ho Chung, MD and Hyun-Seok Lee, MD

Department of Otorhinolaryngology-Head and Neck Surgery, Sungkyunkwan University School of Medicine, Samsung Medical Center, Seoul, Korea

\section{서 론}

Ménière병은 반복되는 발작성 현훈과 청력소실, 이명, 이충만감을 증상군으로 하는 질환이다. 본 질환에서 발생 하는 급성 현훈 발작은 환자에게 심각한 신체적, 정신적 인 고통을 준다. 대부분 30 40대의 사회적인 활동이 많 은 나이에 발생하며 적절한 치료를 받지 못할 경우 직장 생활을 못할 정도로 활동에 많은 제약을 받게 되며, 심한 무기력증과 우울증을 초래하기도 한다.

본 질환의 치료는 크게 내과적인 치료와 외과적인 치료 로 나눌 수 있다. 내과적인 치료법에는 어지러움 발작 시 어지러움과 그와 연관된 증상(오심, 구토 등) 을 완화시 켜주는 치료와 Ménière병의 병인과 관련하여 발작의 재 발을 방지하고, 이명과 청력소실을 완화시키는 치료로 구 별할 수 있다. 후자의 치료 방법에는 식이요법과 약물 복 용, 최근에는 고실내 주입법과 국소압력치료 등이 이용 되고 있다(T able 1).

Ménière병을 가진 환자가 내원하였을 때는 우선적으 로 내과적 치료를 시행한다. 많은 보고에서 내과적 치료 를 일차적인 치료 방법으로 사용하였을 때 약 $80 \%$ 에서 효과가 있는 것으로 알려져 있다. 현재까지 여러 가지 약

교신저자 : 정원호, 135- 710 서울 강남구 일원동 50 성균관대학교 의과대학 삼성서울병원 이비인후과학교실 전화 : (02) 3410- 3579. 전송 : (02) 3410- 3879 E- mail : whchung@smc.samsung.co.kr
제가 본 질환의 치료를 위해 소개되어 왔으나, 대부분의 약제들의 효과를 randomized controlled clinical trial을 바탕으로 분석된 보고가 불충분하다. 이는 아직도 Ménière병의 병태생리가 분명치 않고, 본 증상을 일으킬 수 있는 동물모델이 없기 때문이다.

약물치료의 성과를 평가하는데 있어 반드시 위약효과 (placebo effect) 와 병의 자연경과를 고려해야 한다. 1977 년 T orok은 834편의 보고를 분석하였는데, 다양한 약 물치료가 $60 \sim 80 \%$ 의 환자에서 효과를 보였으나 ${ }^{1)}$ 상당 부분은 위약효과로 설명할 수 있다고 하였다. ${ }^{2)}$ 또한 1991 년 Ruckenstein 등 ${ }^{3)}$ 은 Ménière병의 치료에 관한 많은 보고를 분석한 결과, 내림프 수종에 대한 어떠한 치료도 Menière병의 증상을 경감시키지 못하며, 내림프 수종이 결과적인 병리이지만 병의 진행을 설명하지는 못한다고 하였다. 또한 전정 억제제(vestibular suppressants) 만 이 Menière병의 증상을 호전시키는 유일한 약물인 것처 럼 보이며 어떤 약물치료도 Ménière병의 증상을 예방할 수 있다는 명백한 증거는 없다고 하였다.

또한 Ménière병의 자연경과에 대한 연구를 보면, Silverstein 등이 50 명의 환자에 대한 연구에서 $59 \%$ 의 환 자에서 2 년 후 어지러움 발작이 소실되었으며 $70 \%$ 의 환 자에서 평균 8.7년 후에 어지러움 발작이 소실되었다고 하였다. ${ }^{4)}$ 이는 Ménière병의 자연경과만으로도 시간이 지 남에 따라 어지러움이 소실될 수 있음을 암시한다.

이와 같이 현재까지 알려진 Ménière병에 대한 치료방 법은 논란이 많고 과학적인 근거가 부족한 실정이다. 그 
렇지만 Ménière병의 내과적 치료로서 식이요법(dietary modification), 약물치료, 고실내 약물주입법, 국소압력치 료, 정신상담치료와 재활치료 등이 계속 이용되고 있다. 본 원고에서는 이러한 내과적 치료를 중심으로 최근 문헌 고찰(Pubmed, Cochrane, EMBA SE) 을 통하여 근거 중 심의 효용성을 고찰해 보고자 한다.

\section{급성 발작(Acute Vertigo)시의 치료}

전정 억제제(vestibular suppressants) 와 진토제(antiemetics) 가 많이 사용된다. 어지러움에 대한 작용기전 은 잘 알려져 있지 않으나 급성 어지러움 발작과 동반된 오심과 구토를 조절하는 효과는 증명되어 있다. 약물 치 료와 동반하여 구토로 인한 탈수와 전해질의 불균형을 교 정하는 것이 필요하다.

\section{전정 억제제}

\begin{tabular}{l} 
Diazepam(Valium) \\
소뇌의 GA BA - ergic sy stem을 항진시켜 전정반응을 \\
Table 1. Medical treatment of Ménière's disease \\
\hline Symptomatic treatment of acute attack \\
\hline Vestibular suppressants \\
Antiemetic drugs \\
Anticholinergic \\
Antidopaminergic \\
Antihistamines \\
\hline Primary treatment of endolymphatic hydrops \\
\hline Diet modification \\
Pharmacologic treatment \\
Diuretics \\
Vasodilators \\
Calcium channel blockers \\
ACE inhibitors \\
Steroids \& immunosuppressants \\
Lipoflavins and vitamins \\
Intratympanic gentamicin \\
Non-pharmacologic treatment \\
Ventilation tube insertion \\
Local overpressure treatment \\
Stress reduction \& Psychologic support \\
Vestibular rehabilitation \\
\hline
\end{tabular}

억제함으로써 증상을 호전시키는 것으로 생각되고 있다. 특히 불안이 동반되었을 때 유효하다. 성인에서 $5 \mathrm{mg}$ 을 3시간마다 경구 복용할 수 있으며 초기의 $5 \mathrm{mg}$ 은 정맥 주사하는 것도 좋다. 부작용으로는 주간의 진정(day time sedation) 이 가장 흔하고 어지러움, 보행실조(ataxia) 등 이 있다. 정맥 주사 후에 호흡억제, 무호흡, 심정지 등이 드물게 발생할 수 있으므로 만성폐쇄성호흡기질환이나 수 면무호흡증이 있는 환자, 고령이나 만성질환으로 전신상 태가 나쁜 경우 등에서는 신중히 사용해야 한다.

\section{진토제}

Anticholinergic

Gly copy rrolate( Robinul)

Diazepam과 같이 투여할 경우 특히 오심과 구토에 효 과가 좋다. 통상 성인에서 1 2 mg을 경구 투여한다. 0.1 $0.2 \mathrm{mg}$ 을 4시간마다 정맥 주사할 수도 있다. 부작용으 로는 구강건조, 시야의 왜곡, 전립선비대의 악화 등이 있 다. 녹내장 glaucoma) 이나 증상이 있는 전립선비대가 있 는 환자에서는 상대적인 금기이다.

Antidopaminergic

Droperidol( Inapsine)

Butyrophenone계열의 약물로 오심과 구토에 효과가 있 다. 추체외로( extrapyramidal) 증상이나 저혈압, 진정작 용 등이 간혹 나타나지만 phenothiazine 계열의 약물보 다는 적다. 성인에서는 $2.5 \sim 10 \mathrm{mg}$ 을 경구투여하거나 5 $\mathrm{mg}$ 을 정맥주사한다.

\section{Prochlorperazine( Compazine)}

Piperazine phenothiazine 계열의 약물로 오심과 구토 에 효과가 있으며 진통제나 진정제의 작용을 항진시킨다. $10 \mathrm{mg}$ 을 경구나 정맥주사로 4 6시간마다 투여할 수 있 다. $50 \%$ 의 환자에서 소량을 사용하여도 졸음(drowsiness) 과 경증의 저혈압을 유발할 수 있다. 치료용량에서 파킨슨병과 유사한 추체외로 증상이 나타날 수 있다. 과 량이 투여되면 의식의 혼탁, 축동, 중증의 저혈압, 심장의 
이상 등이 발생할 수 있다.

Antihistamines

Dimenhy drinate( Dramamine)

Menière병에서 현훈의 급성 발작과 예방에 모두 효과 적이며 오심과 구토에도 효과가 있다. 가벼운 졸음이 발 생할 수 있으며 50 100 mg을 하루 3 4회 경구복용할 수 있으며 근육주사나 정맥주사도 가능하다.

Diphenhy dramine( Benadryl)

보통 $50 \mathrm{mg}$ 을 경구투여하며 작용시간은 4 6시간이다. 졸음이 많이 발생한다.

Meclizine( A ntivert, bonine)

전정반응에 의한 구토의 예방과 치료에 가장 많이 쓰이 는 약제 중 하나다. 작용시간이 느리며 24시간 동안 효 과가 지속된다. 졸음, 시야의 흐림, 구강건조, 피로감 등이 발생할 수 있다. 현훈의 치료에는 25 100 mg을 분할 투 여할 수 있다.

Promethazine(Phenergan)

다른 phenothiazine 계열의 약물과 달리 antihistaminic activity 와 central cholinergic blocking activity 가 강하다. 초기 용량은 $25 \mathrm{mg}$ 이며 4 6시간마다 12.5 25 $\mathrm{mg}$ 을 추가할 수 있다. 장점으로는 직장을 통해 투여할 수 있으므로 오심이 심하여 경구투여가 어려울 때 사용 할 수 있다. 통상적인 용량에서는 졸음이 유발되기도 하 지만 추체외로 증상은 적다.

Hy droxy zine

1일 25 50 mg을 사용하면 진통효과와 항불안효과도 같이 있어 효과적이다.

\section{Ménière병의 근본적 치료}

Ménière병의 근본적 치료는 본 질환의 병리기전으로 알 려져 있는 내림프수종을 완화하여 현훈의 재발을 방지하 고 청력을 유지하는 데 있다. 이러한 근본 요법에는 크게
식이요법과 약물요법 및 비약물적 요법이 있다. 각 치료 요법에 대한 효능성은 Pubmed(http://www.ncbi.nlm. nih.gov/entrez/query/static/clinical.shtml), Cochrane (http://www .cochrane.org/index 0.htm), EMBA SE (http://www .embase.com/) 의 데이터베이스를 이용하여 근거중심으로 설명하고자 하였다.

\section{식이요법(Diet modification)}

1934년 Furstenberg 등은 Ménière병의 증상이 염 분의 축적에 의한다고 보고하면서, 저염식과 이뇨제가 현 훈 발작을 조절할 수 있다고 하였다. ${ }^{5)}$ 1975년 Boles 등 도 다시 저염식과 이뇨제의 효과에 대해 보고하였다. ${ }^{6)}$ 그 들은 대부분의 환자에서 1 일 800 1000 mg의 저염식으 로 현훈이 조절되었다고 하였다. 1981년 Jackson 등은 저염식으로 $57.9 \%$ 의 성공률을 보고하였다. ${ }^{7)}$ 그러나 아 직까지 저염식이 내림프수종에 영향을 미친다는 과학적 인 근거는 불충분하다. 단지 대부분 사람들이 필요 이상 의 염분을 섭취하고 있고, 과다한 염분의 축적이 내림프 의 저류를 일으킨다고 생각하고 있다. 일반적으로 권장되 는 염분의 양은 1 일 $1500 \mathrm{mg}$ 이하이다. 그러나 이러한 엄격한 기준을 적용할 경우 환자의 순응도가 떨어지므로 실제적으로는 짠 음식을 피하고, 조리중이나 조리된 음식 에 소금을 첨가하지 않도록 교육한다. 그리고 카페인, 니 코틴, 알코올의 섭취를 제한하도록 교육한다.

\section{약물치료요법(Pharmacologic treatment)}

이노제(Diuretics)

이뇨제는 내림프액을 감소시켜 내림프 수종을 교정할 수 있다는 이론적 근거에 의해 사용되어왔다. 1962년 Norell 등이 Ménière병에서 처음으로 hydrochlorothiazide (HCT Z) 를 처음으로 사용하였다. ${ }^{8)}$ Menière병에서 이뇨 제를 이용한 randomized controlled study (RCT) 가 시 행된 경우는 Pubmed에서 검색하였을 때 두개의 보고가 있다. 1967년 Klockhoff와 Lindblom 등 ${ }^{9}$ 이 HCT Z의 효과에 대하여 보고하면서, 50 명의 환자 중 $75 \%$ 에서 증 상의 조절에 효과가 있었으며 위약군에서는 효과가 없었 다고 한다. Van Deelen과 Huizing은 ${ }^{10)}$ Dyazide가 위 약군(<10\%)에 비해 유의하게( $51 \%)$ 어지러움 발생 억 
제에 효과가 있었다. 그러나, 청력이나 이명에는 효과가 없었다고 하였다.

Thiazide diuretics는 신장에서 나트륨의 재흡수를 차 단함으로써 이뇨를 유발한다. 부작용으로는 저칼륨혈증, 고혈당, 고요산혈증, 저혈압, 고지혈증 등이다. Glycerol 과 같은 삼투성 이뇨제는 일부 환자에서 수종을 감소시 키는 것으로 보이지만 효과의 지속시간이 매우 짧은 것으 로 알려져 있다.

Hy drochlorothiazide

보통 칼륨의 보충이 필요하며 성인에서는 보통 하루 50 $\mathrm{mg}$ 을 경구복용한다.

Dy azide

$\mathrm{HCT}$ Z와 triamterene( potassium sparing diuretic)의 복합제재로 따로 칼륨의 보충이 필요없다.

\section{Furosemide( Lasix)}

Loop diuretics 중 하나로, ascending loop of Henle 에서 chloride의 재흡수를 차단하므로 나트륨과 칼륨이 소 변으로 배출되고 대사성 알칼리증을 유발한다. 부작용으 로는 과도한 이뇨, prerenal azotemia, 저혈압 등이 있다. T hiazide diuretics에 비해 전해질의 불균형과 탈수가 쉽 게 발생하고, 특히 저칼륨혈증은 digitalis therapy 를 병 행할 경우 심각하다. 성인의 용량은 하루 $10 \sim 80 \mathrm{mg}$ 이 며 15분내에 효과가 나타나며 4시간 지속된다.

\section{A miloride}

신장의 원위세뇨관에 작용하여 칼륨의 분비를 억제한 다. 자체로는 이뇨작용이 약하므로 보통 다른 이노제와 같 이 사용하여 칼륨의 소실을 최소화한다. Moduretic은 HCT Z와 amiloride의 복합제재이다.

\section{A cetazolamide( Diamox)}

Carbonic anhydrase inhibitor 로 근위세뇨관에서 sodium bicarbonate의 재흡수를 차단한다. Corvera는 ${ }^{11)}$ acetazolamide와 chlorthalidone이 현훈 발작에 비슷한 정도의 효과를 보인다고 하였으며 단기적인 청력의 개선 효과가 있다고 하였다. 그러나, 현훈에는 효과가 있으나
장기적인 청력의 악화를 막지는 못하는 것으로 알려져 있 다. 부작용으로 감각이상, 위장관의 부작용, 식욕부진, 졸 음, 피로감, 일시적 축동 등이 있다. 또한 요산( uric acid) 의 배설을 억제함으로써 통풍을 유발할 가능성이 있다. 이러한 부작용으로 장기적인 처방은 좋지 않으며 통상 성 인에서 250 $500 \mathrm{mg}$ 을 경구복용한다.

\section{Methazolamide( Neptazane)}

Carbonic anhydrase inhibitor 로 대부분의 Ménière병 환자에서 효과가 있다고 알려져 있어 thiazide diuretics 의 대용으로 사용될 수 있다. 보통 3개월 동안 하루 50 $150 \mathrm{mg}$, 주 5일 복용한다. 초기에는 칼륨의 보충이 필요 하다. 부작용으로는 피부발진, 두통, 설사 등이 있으며 sulfa allergy, 만성폐쇄성폐질환, 간이나 신장의 기능이상 등 에서는 금기이다.

\section{혈관확장제(vasodilators)}

혈관확장제의 사용은 Menière병이 혈관조( stria vascularis) 의 허혈에 의해 발생한다는 가설에 근거한 것이 다. 그러나 허혈과 수종의 인과관계는 아직 밝혀지지 않 았다. Histamine, betahistine, nicotinic acid 등이 사용 된다. Betahistine은 histamine 유사약제로써 여러 randomized controlled study 를 통하여 Ménière병의 현훈 에 효과가 있다고 보고되고 있다. 그러나 2001년 James 등 $^{12)}$ 이 여러 연구를 분석하여 systemic review 를 보고 한 바에 따르면 거의 모든 연구에서 betahistine의 효과 에 대한 근거가 불충분하며 이명과 청력에는 효과가 없 다고 하였다. 그러나 부작용이 없는 안전한 약제이므로 유럽 지역에서는 많이 사용되고 있다.

\section{Calcium channel blockers}

Nimodipine은 혈액뇌장벽을 통과하는 약제로 이뇨제 에 반응이 없는 Ménière병 환자에서 효과가 있는 것으로 최근 보고되고 있다. ${ }^{13)}$ 지주막하출혈( subarachnoid hemorrhage)에서 혈관의 연축을 감소시키는 효과로 FDA 가 승인한 약제이다.

내이 유모세포의 칼슘 농도를 조절하거나 중추에서 작 용하는 것으로 생각된다. 보통 $30 \mathrm{mg}$ 을 1일 2회 복용하 며, 위장관장애가 가장 흔한 부작용이다. 가격이 비싼 것 
이 단점이다.

ACE inhibitors

Renin- angiotensin- aldosterone system을 차단함으 로써 혈관을 확장시키며 나트륨의 배설을 증가시킨다. 그 리고 기전은 알려져 있지 않으나 신장에서 자유수분의 배 설을 항진시킨다. 저혈압, 신부전이 있을 때는 사용이 어 렵다.

\section{스테로이드 및 면역억제제}

Ménière병이 자가면역질환이라는 가설에 근거를 두고 스테로이드를 비롯한 면역억제제가 치료에 사용되어왔다. 자가면역질환에서 흔히 양측성 청력소실을 일으키는 것으 로 보아 양측성 Menière병의 원인이 자가면역성질환으로 생각할 수 있다. 또한 Rauch 등은 30\% 의 양측성 Ménière병 환자의 혈청에서 heat shock protein 70 에 대 한 circulating antibody 가 발견되었다고 보고하였다. 그 러나 아직 스테로이드가 Menière병에 효과가 있다는 과 학적인 근거는 없다. 양측성인 경우나 돌발성 청력소실 이 있고, 변동하는 청력을 보이는 경우에 경구용 스테로이 드를 사용할 수 있겠다.

최근에는 스테로이드를 고실내 주입하는 보고가 많다. Shea는 ${ }^{14)}$ 약물에 반응하지 않는 Ménière병 환자 48명 에서 dexamethasone을 고실내 주입하고 2년 동안 추적 관찰하였다. 이 연구에서 $66.7 \%$ 에서 현훈이 소실되었다 고 보고하였다. Sennaroglu는 ${ }^{15)}$ 환기관을 유치하고 격 일로 3개월 동안 dexamethasone을 주입하였을 때 $72 \%$ 에서 현훈이 호전되었고 $16 \%$ 에서 청력이 개선되었으며 $38 \%$ 에서는 청력이 감소하였다고 하였다. Barrs는 ${ }^{16)} 1$ 개월 동안 매주 반복 주입하는 방법으로, 첫 3 개월 후 $86 \%$ 에서 현훈이 호전되었고 6 개월 후에는 $43 \%$ 에서 호전되 었다고 하였다. 그러나 이러한 보고들은 연구마다 방법이 다르고 단기간의 결과를 분석한 것이므로 비교하기는 어 렵다. 결론적으로 고실내 스테로이드 주입은 전신적 부작 용이 없고 덜 침습적인 방법이며 청력저하의 위험이 거의 없다는 장점이 있으나 치료기간이 길고 시간이 지나면 효 과가 없어진다는 단점이 있다.

내이의 증상을 보이는 자가면역질환에서 면역억제제나막 plasmapheresis, ${ }^{18)}$ immunoglobulin G with methy I
$\mathrm{B} 12^{19)}$ 를 사용한 연구가 있으나 Ménière병 자체에서 면 역억제제의 효과를 증명한 연구는 없다.

기타 약물

Lipoflavins and vitamins

Williams 등 $^{20)}$ 은 국소적으로 histamine이 과량 유리 되면 항상성이 파괴되고 Ménière병의 증상이 유발된다 고 하였다. Eriodicty lol gly coside( lemon bioflavonoid extract) 는 histidine decarboxy lase를 차단하여 histamine의 과생성을 억제함으로써 Ménière병의 증상에 효 과가 있다는 가설이 있다. Williams 등은 122 명의 Menière 병 환자에서 lemon bioflavonoid complex 로 치료하여 현훈과 청력에 효과가 있다고 하였다. ${ }^{20)}$

\section{Famciclovir}

Derebery 등은 12 명의 Ménière병 환자에서 famciclovir를 사용하고 11 명의 위약군과 비교하였는데, 청력 의 변동을 억제하는 효과는 있으나 현훈에는 거의 효과가 없다고 보고하였다. ${ }^{21)}$

\section{고실내 곈타마이신 주입술}

식이요법과 약물치료로 증상이 조절되지 않는 경우 수 술적 치료나 chemical ablation을 고려한다. Chemical ablation의 개념은 1940년대 후반 결핵 치료를 위해 streptomy cin을 근육주사하는 환자에서 말초전정기관의 기능 이 소실되는 것이 알려지면서 Ménière병 환자에 이용되 었다. ${ }^{22)}$ 1978년 Beck과 Schmidt 등 ${ }^{23)}$ 은 겐타마이신을 이용한 고실내 주입의 치료성적을 발표하였다.

고실내 겐타마이신 주입술의 원리는 이독성 약물로 알 려진 겐타마이신을 이용하여 전정기능을 부분적 또는 완 전히 파괴하여 현훈을 조절하는 것이다. 그러나 최근에 는 내림프의 생성에 관여하는 전정기관의 암세포( dark cell) 를 손상시켜 내림프의 감소를 일으켜 Menière병에서 효 과가 있다는 이론이 있다. ${ }^{24}{ }^{26)}$ 고실내 겐타마이신 주입 이 신경상피세포보다 먼저 암세포를 손상시키는 것을 증 명한 동물실험이 있으날) ${ }^{26)}$ 인간에서 선택적으로 암세 포가 파괴되는 것은 증명되지 않았다. ${ }^{27) 28)}$

많은 치료자들이 고실내 겐타마이신 주입술의 우수한 결 
과를 보고하지만 아직 Ménière병의 표준적인 치료로 확 립되지는 못하였다. 이것은 본 주입술의 작용기전과 약물 동력학(pharmacokinetics) 이 불분명하고 치료자에 따라 투여방법, 용량, treatment protocol 등이 다르기 때문 이다.

\section{약물동력학(Pharmacokinetics)}

고실내 주입후에 겐타마이신이 내이로 흡수되는 기전 에 대하여 많은 이론이 제시되고 있다. 정원창 round window), 난원창(oval window), 혈관이나 림프관, 이낭의 작은 열공(small lacunae in the otic capsule) 등을 통하 여 내이로 흡수될 것이라고 생각된다. 정원창은 고유층 (lamina propria) 과 상피층의 막으로 구성되는 가장 얇은 장벽이므로 주된 흡수경로(entry site) 로 생각되고 있 다. $^{29}{ }^{30)}$ 고실내 주입 후 내이의 겐타마이신 농도는 지속 적으로 상승하여 약 2 일째 최고농도에 이른다. 겐타마이 신이 외림프에 남아있는 시간에 대해서는 연구자들마다 의견이 다르다. 2001 년 Hibi 등에 의하면 내이에서 겐타 마이신의 배설이 아주 빨라서( 반감기가 75분) 내이에서 고농도를 만들고자 할 때는 많은 양을 주입하거나 지속 적으로 유리되는 방법( sustained release vehicle) 을 사 용해야 된다고 하였다. ${ }^{31)}$

환자에 따라 IT GM에 대한 반응정도( susceptibility) 가 다를 수 있다. 동량의 약물을 주입하더라도 정원창에 접 촉되어있는 양이 다르며 접촉되어있는 시간도 다를 것이 다. 내이로 흡수되는 양은 정원창의 두께, 정원창와(round window niche) 주위의 반흔 또는 유착의 유무, 와 우도수관( cochlear aqueduct) 의 개방 정도(patency), 머 리의 방향, 이관의 개방 정도 등에 따라 달라질 수 있다. 외림프와 내림프의 turnover rate도 겐타마이신의 배설 에 영향을 줄 수 있다. ${ }^{32)}$ 동물이나 ${ }^{33)}$ 인간에서 ${ }^{34)}$ 와우도 수관을 폐쇄하더라도 내이의 조직학적 또는 기능적인 변 화는 관찰되지 않았으나, 와우도수관의 internal orifice 가 정원창과 근접해 있기 때문에 와우도수관으로의 외림 프 흐름이 차단된다면 와우내의 약물의 배설이 지연될 것 이라는 가설이 있다. ${ }^{35)}$ 전신적인 aminoglycoside 투여후 에 양쪽 와우의 손상정도가 차이가 나는 것도 이러한 기 전으로 설명할 수 있을 것이다.
주입 방법(Administration modalities)

고실내로 겐타마이신을 주입하는 방법에는, 고막을 통 한 직접 주사 injection through the intact ty mpanic membrane), 환기관을 통한 주입, 미세관(microcatheter) 을 통한 주입, sustained release vehicle의 이용, 이 관을 통한 주입 등이 보고되었다. 방법의 선택은 주입의 빈도와 환자의 편의성에 따라 선택할 수 있다. 하루 수차 례 주입한다면 환기관이나 transty mpanic catheter 를 이 용하는 것이 편리하지만 만성 고막 천공이 발생할 수 있 다. 고막을 통하여 직접 주사하는 방법은 빠르고 쉽고 비 용이 저렴하다. 이 방법은 1주에 한 번 주입하거나 병원 을 자주 올 수 없는 환자들에게 유용하다. Sustained release vehicle(fibrin glue, gelfoam, active delivery device) 을 이용하는 방법은 겐타마이신을 정원창에 더 근 접하게 하므로 와우 독성을 최소화할 수 있을 것이다. 그 러나 이 방법은 기술적으로 어렵고 시술을 견디기 힘든 환자도 있다.

IT GM의 적절한 용량은 아직 확립되지 않았다. 적은 용량 4 40 mg) 이라도 청력에 영향을 미칠 수 있기 때 문이다. Vestibular ablation에 필요한 용량은 저자마다 차이는 있으나 10 40 mg/ml이다. ${ }^{36)}$

IT GM을 주입하는 protocol은 크게 titration(variable end- point) technique과 fixed(predetermined dose) technique의 두 가지로 나눌 수 있다. Fixed technique 에서는 대개 적어도 하루 한번 이상 주입하고, titration technique에서는 1주에 한번 정도 주입한다. Titration 법은 연속적으로 주입하면서 내이 독성을 조기에 발견할 수 있는 장점이 있으나 치료 기간이 길어지므로 병원을 자주 올 수 없는 환자들에서는 사용하기 어렵고 이미 청 력이 나쁜 환자에서는 유용하지 못하다. ${ }^{37)}$ 그러나 fixed technique에서도 치료에 반응이 없을 겨우 반복해서 시 행하는 경우가 많기 때문에 두 protocol을 명확히 구분 할 수는 없다.

\section{치료성적}

2004년 Cohen- Kerem 등 ${ }^{38)}$ 은 1985년에서 2003년 까지 고실내 겐타마이신 주입술과 관련된 논문중에서, A merican- A cademy of Otolayngology Head and Neck Surgery (AAO- HNS) 가 Ménière병에 대하여 제시한 
기준에 부합되는 15 편의 논문에서 627 명의 환자를 메타 분석하였다. 15 편의 논문 전부 시술 시행 전후를 비교하 였으며 환자 본인이 대조군이 되는 연구였다. 분석 결과 를 보면, 현훈의 완전한 조절(class A) 은 $74.7 \%$ (67.8 $81.5 \%$ ) 이었고 class B 이상으로 호전된 경우는 $92.7 \%$ (89.5 96.0\%) 였다. 치료의 성공률에서 protocol에 따른 차이는 없었다 (fixed vs. titration). 청력에는 거의 영향 이 없었으며 protocol에 따른 차이는 없었다. Functional level의 분석은 자료의 부족으로 시행할 수 없었다.

저자들도 1997년부터 통상적인 약물치료에 반응하지 않는 환자를 대상으로 고실내 겐타마이신 주입술을 시행 하고 있다. 겐타마이신의 농도는 $40 \mathrm{mg} / \mathrm{cc}$ 를 사용하였 고 고막내 직접 주사하는 방법을 이용하였다. 1997년부 터 2005년 2월까지 총 30명의 환자에서 시행되었으며, 처음 10명에서는 고용량 1회 $20 \mathrm{mg}$ 을 1일 간격으로 2 회이상 (2 10회) ] 을 주입하였고, 이후부터는 저용랭 $0.3 \mathrm{cc}$ (12 mg)을 1회] 을 사용하였다. Class A 또는 B로 호전 된 경우는 고용량군과 저용량군에서 모두 $90 \%$ 이었다. 청 력은 고용량군의 $71 \%$ 에서, 저용량군에서는 $11 \%$ 가 감소 하여 저용량군에서 청력감소가 적었다. 어지러움증의 치 료성적은 양군에서 비슷하지만, 청력소실의 가능성이 고 용량군에서 월등히 증가함으로 저자들은 저용량의 protocol을 사용하고 있다. .

\section{비약물치료요법(Non-pharmacologic treatment)}

\section{중이 환기관 삽입술}

T umarkin과 ${ }^{39)}$ Lall에 $^{40)}$ 의해 최초로 Menière병 환자 에서 시도되었다. Montandon 등 ${ }^{41)}$ 은 28 명의 환자에서 2 년 동안 추적관찰한 결과 $82 \%$ 에서 현훈의 재발을 방지 한다고 보고하였다. 환기관 삽입술의 이론적 배경은 수종 성 내이가 저산소상태에 있다는 점이다. 내이의 내림프압 이 상승하면 저산소증을 악화시키고 또다시 내림프수종 이 더욱 악화된다. 환기관을 삽입하면 중이내에 산소분압 이 상승하고 내이의 저산소증(anoxia) 를 개선하여 내림 프압을 낮추는데 도움이 된다는 이론이다.

국소압력치료(Local overpressure treatment)

다이빙을 하거나 비행기를 타고 있을 때 주위의 압력
이 변화하면 내이의 증상이 나타나는 것을 관찰할 수 있 는데, 이러한 원리를 이용하여 국소압력치료를 Ménière 병의 치료에 도입하게 되었다.

Densert 등 ${ }^{42)}$ 과 Ingelstedt 등 ${ }^{43)}$ 이 중이에 고압을 유 발하면 Ménière병 환자의 급성 증상이 호전됨을 보이면 서 임상연구가 시작되었다. 중이의 압력이 내이수종에 작 용하는 기전에 대하여 여러 가설이 제시되고 있으나 중 이의 압력 상승이 내림프의 배출을 증가시키는다는 것이 주된 이론이다. 특히 와우도수관을 폐쇄시키면 내림프의 배출이 더욱 증가한다고 한다. ${ }^{44)}$

Densert 등 ${ }^{45)}$ 은 일련의 동물실험에서 pressure chamber를 통한 압력의 전달보다 중이와 정원창을 통한 직접 적인 압력의 전달이 더 효과적이며 complex pressure wave가 현저한 내이의 압력변화를 유발한다고 하였다. Ménière병 환자에서 pressure pulse를 준 후 electrocochleography 를 측정한 결과 위약군에 비해 호전된 결 과를 얻었다는 보고도 있다. ${ }^{46)}$

Meniett는 1999년 FDA 의 승인을 받은 low pressure generator 로 현재까지 세계적으로 1,500명 이상의 환자 에서 사용되었다. ${ }^{47)}$ 환기관 삽입 후 사용하는데, 0 20 $\mathrm{cmH}_{2} \mathrm{O}$ 의 complex pressure wave를 발생한다. Pressure pulse가 1분 지속되고, 40 초 동안 멈추는 것을 3 회 반복하면 한번의 치료(session) 가 되므로 한번에 약 5 분이 소요된다.

2001년 Odkvist는 ${ }^{48)}$ Meniett 치료후 현훈이 의미있 게 감소하였다고 하였으며 일부의 환자에서는 $250 \mathrm{~Hz}$, $500 \mathrm{~Hz}, 2 \mathrm{kHz}$ 에서 청력이 호전되었다고 한다. 2004년 Gates 등 ${ }^{49}$ 은 62 명을 대상으로 4 개월간 관찰한 결과 Meniett 치료후 현훈이 현저히 개선되었다고 보고하였다. 2005년 Thomsen 등 ${ }^{47)}$ 은 Meniett 치료를 받은 20명 에서 현훈이 의미있게 감소했으나 이명, 이충만감, 청력은 대조군과 차이가 없었다고 한다.

스트레스 감소 및 정신심리유지(Stress reduction and psychological support)

Ménière병 환자가 강박적이고 완벽한 성격에서 많이 나타난다고 한다. 이러한 성격의 소유자는 주로 스트레 스에 약하며, 스트레스에 의해 체내의 호르몬의 이상이 생기면서 염분의 저류가 발생할 수 있다. 따라서 여러가 
지 스트레스를 줄이는 요법들이 보조적으로 이용되고 있 다. 심리요법, biofeedback과 같은 정신 상담 치료가 사 용될 수 있다. 또한 필요한 경우 적은 양의 전정억제제 를 투여하여 심리적인 안정을 취하게 하는 경우도 있다. 반복적인 현훈으로 일상적인 생활에서의 상실감이나 사 회적 능력의 소실로 우울증을 느끼는 경우가 많다. 이러 한 경우 만성 우울증으로 진행되지 않도록 상담치료가 필 요하고 필요하면 amitry ptiline 등의 항우울제를 처방한다.

\section{전정재활운동}

Ménière병 환자에서 일측성 전정장애의 소견을 보이 면서 발작기가 아닌 경우에도 어지러운 증상을 보이는 경 우가 있다. 이러한 경우 전정재활운동이 증상 호전에 도 움이 된다. 또한 종종 체위성 어지러움을 호소하면서 DixHallpike test나 positional test 양성 반응을 보이는 양 성발작성두위변환성 어지러움증(BPPV)이 동반되는 경 우가 있다. 이러한 경우 이석 정복술을 시행하여 증상의 완화를 가져올 수 있다.

\section{결 론}

내과적인 치료로 Ménière병 환자의 약 $80 \%$ 에서 증상 이 호전되며 고실내 겐타마이신의 주입은 약물치료에 잘 듣지 않는 환자에서 좋은 성적이 보고되고 있다. 그러나, 근거중심으로 살펴보았을 때, 현재 시행되고 있는 약물 치료는 근거가 충분치 않음을 알 수 있다. 향후 Menière 병의 병태생리가 추가로 밝혀지고 추가적인 임상 연구가 시행된다면 효과적인 치료 방법이 확립되리라 생각된다.

중심 단어 : Menière병. 약물 치료. 비 약물 치료. 고실 내 주입술.

\section{REFERENCES}

1) Torok N. Old and new in Meniere disease. Laryngoscope 1977;87:1870-7.

2) Brookes GB. Medical management of Meniere's disease. Ear Nose Throat J 1997;76:634-40.

3) Ruckenstein MJ, Rutka JA, Hawke M. The treatment of Meniere's disease: Torok revisited. Laryngoscope 1991;101: 211-8.

4) Silverstein H, Smouha E, Jones R. Natural history vs. surgery for Meniere's disease. Otolaryngol Head Neck Surg
1989;100:6-16.

5) Furstenberg AC, Lashmet FH, Lathrop F. Meniere's symptom complex: medical treatment. 1934. Ann Otol Rhinol Laryngol 1992;101:20-31.

6) Boles R, Rice DH, Hybels R, Work WP. Conservative management of Meniere's disease: Furstenberg regimen revisited. Ann Otol Rhinol Laryngol 1975;84:513-7.

7) Jackson CG, Glasscock ME, 3rd, Davis WE, Hughes GB, Sismanis A. Medical management of Meniere's disease. Ann Otol Rhinol Laryngol 1981;90:142-7.

8) Norell I, Stahle J. Treatment of Meniere's disease with hydrochlorothiazide. Acta Otolaryngol 1962;54:447-56.

9) Klockhoff I, Lindblom U. Meniere's disease and hydrochlorothiazide (Dichlotride)--a critical analysis of symptoms and therapeutic effects. Acta Otolaryngol 1967;63:347-65.

10) van Deelen GW, Huizing EH. Use of a diuretic (Dyazide) in the treatment of Meniere's disease. A double-blind crossover placebo-controlled study. ORL J Otorhinolaryngol Relat Spec 1986; $48: 287-92$.

11) Corvera J, Corvera G. Long-term effect of acetazolamide and chlorthalidone on the hearing loss of Meniere's disease. Am J Otol 1989;10:142-5.

12) James AL, Burton MJ. Betahistine for Meniere's disease or syndrome. Cochrane Database Syst Rev 2001:CD001873.

13) Slattery WH 3rd, Fayad JN. Medical treatment of Meniere's disease. Otolaryngol Clin North Am 1997;30:1027-37.

14) Shea JJ Jr, Ge X. Dexamethasone perfusion of the labyrinth plus intravenous dexamethasone for Meniere's disease. Otolaryngol Clin North Am 1996;29:353-8.

15) Sennaroglu L, Sennaroglu G, Gursel B, Dini FM. Intratympanic dexamethasone, intratympanic gentamicin, and endolymphatic sac surgery for intractable vertigo in Meniere's disease. Otolaryngol Head Neck Surg 2001;125:537-43.

16) Barrs DM, Keyser JS, Stallworth C, McElveen JT Jr. Intratympanic steroid injections for intractable Meniere's disease. Laryngoscope 2001;111:2100-4.

17) Sajjadi H. Medical management of Meniere's disease. Otolaryngol Clin North Am 2002;35:581-9.

18) Brookes GB, Newland AC. Plasma exchange in the treatment of immune complex-associated sensorineural deafness. J Laryngol Otol 1986;100:25-33.

19) Futaki $T$, Semba T, Kudo Y. Treatment of hydropic patients by immunoglobulin with methyl B12. Am J Otol 1988;9: 131-5.

20) Williams HL, Maher FT, Corbin KB, Brown JR, Brown HA, Hedgecock LD. Eriodictyol Glycoside In The Treatment Of Meniere's Disease. Ann Otol Rhinol Laryngol 1963;72: 1082-101.

21) Derebery MJ, Fisher LM, Iqbal Z. Randomized double-blinded, placebo-controlled clinical trial of famciclovir for reduction of Meniere's disease symptoms. Otolaryngol Head Neck Surg 2004;131:877-84.

22) Schuknecht HF. Ablation therapy in the management of Meniere's disease. Acta Otolaryngol 1957;47:1-42.

23) Beck C, Schmidt CL. 10 years of experience with intratympanally applied streptomycin (gentamycin) in the therapy of Morbus Meniere. Arch Otorhinolaryngol 1978;221:149-52.

24) Ge X, Shea JJ Jr. Scanning electron microscopic observa- 
tion of dark cells after streptomycin perfusion of the vestibule in guinea pigs. Scanning Microsc 1995;9:283-8.

25) Park JC, Cohen GM. Vestibular ototoxicity in the chick: effects of streptomycin on equilibrium and on ampullary dark cells. Am J Otolaryngol 1982;3:117-27.

26) Pender DJ. Gentamicin tympanoclysis: effects on the labyrinthine sensory cells. Laryngoscope 2003;113:343-8.

27) Hone SW, Nedzelski J, Chen J. Does intratympanic gentamicin treatment for Meniere's disease cause complete vestibular ablation? J Otolaryngol 2000;29:83-7.

28) Thomsen J, Charabi S, Tos M. Preliminary results of a new delivery system for gentamicin to the inner ear in patients with Meniere's disease. Eur Arch Otorhinolaryngol 2000; 257:362-5.

29) Kawauchi H, DeMaria TF, Lim DJ. Endotoxin permeability through the round window. Acta Otolaryngol Suppl 1989; 457:100-15.

30) Goycoolea MV, Muchow D, Schachern P. Experimental studies on round window structure: function and permeability. Laryngoscope 1988;98:1-20.

31) Hibi T, Suzuki T, Nakashima T. Perilymphatic concentration of gentamicin administered intratympanically in guinea pigs. Acta Otolaryngol 2001;121:336-41.

32) Hirsch BE, Kamerer DB. Role of chemical labyrinthectomy in the treatment of Meniere's disease. Otolaryngol Clin North Am 1997;30:1039-49.

33) Kimura RS, Schuknecht HF, Ota CY. Blockage of the cochlear aqueduct. Acta Otolaryngol 1974;77:1-12.

34) Gopen Q, Rosowski JJ, Merchant SN. Anatomy of the normal human cochlear aqueduct with functional implications. Hear Res 1997;107:9-22.

35) Walsted A. Unpredictable hearing loss after intratympanic gentamicin treatment for vertigo. A new theory. Acta Otolaryngol 2001;121:42-4.

36) Hoffer ME, Kopke RD, Weisskopf P, Gottshall K, Allen K, Wester $\mathrm{D}$, et al. Use of the round window microcatheter in the treatment of Meniere's disease. Laryngoscope 2001;111: 2046-9.

37) McFeely WJ, Singleton GT, Rodriguez FJ, Antonelli PJ. Intratympanic gentamicin treatment for Meniere's disease.
Otolaryngol Head Neck Surg 1998; 118:589-96.

38) Cohen-Kerem R, Kisilevsky V, Einarson TR, Kozer E, Koren G, Rutka JA. Intratympanic gentamicin for Meniere's disease: a meta-analysis. Laryngoscope 2004;114:2085-91.

39) Tumarkin A. Thoughts on the treatment of labyrinthopathy. J Laryngol Otol 1966;80:1041-53.

40) Lall M. Meniere's disease and the grommet (a survey of its therapeutic effects). J Laryngol Otol 1969;83:787-91.

41) Montandon P, Guillemin P, Hausler R. Prevention of vertigo in Meniere's syndrome by means of transtympanic ventilation tubes. ORL J Otorhinolaryngol Relat Spec 1988;50: 377-81.

42) Densert $\mathrm{O}$, Ingelstedt $\mathrm{S}$, Ivarsson $\mathrm{A}$, Pedersen $\mathrm{K}$. Immediate restoration of basal sensorineural hearing (Mb Meniere) using a pressure chamber. Acta Otolaryngol 1975;80:93-100.

43) Ingelstedt $\mathrm{S}$, Ivarsson $\mathrm{A}$, Tjernstrom O. Immediate relief of symptoms during acute attacks of Meniere's disease, using a pressure chamber. Acta Otolaryngol 1976;82:368-78.

44) Konradsson KS, Carlborg AH, Farmer JC Jr, Carlborg BI. Perilymph pressure during hypobaric conditions--cochlear aqueduct obstructed. Acta Otolaryngol 1994;114:24-9.

45) Densert B, Densert O, Erlandsson B, Sheppard H. Transmission of complex pressure waves through the perilymphatic fluid in cats. Acta Otolaryngol 1986;102:403-9.

46) Densert B, Densert O, Arlinger S, Sass K, Odkvist L. Immediate effects of middle ear pressure changes on the electrocochleographic recordings in patients with Meniere's disease: a clinical placebo-controlled study. Am J Otol 1997; 18:726-33.

47) Thomsen J, Sass K, Odkvist L, Arlinger S. Local overpressure treatment reduces vestibular symptoms in patients with Meniere's disease: a clinical, randomized, multicenter, double-blind, placebo-controlled study. Otol Neurotol 2005;26: 68-73.

48) Odkvist L. Pressure treatment versus gentamicin for Meniere's disease. Acta Otolaryngol 2001;121:266-8.

49) Gates GA, Green JD Jr, Tucci DL, Telian SA. The effects of transtympanic micropressure treatment in people with unilateral Meniere's disease. Arch Otolaryngol Head Neck Surg 2004; 130:718-25. 